\title{
JPT1 wt Allele
}

National Cancer Institute

\section{Source}

National Cancer Institute. JPT1 wt Allele. NCI Thesaurus. Code C114590.

Human JPT1 wild-type allele is located in the vicinity of $17 q 25.1$ and is approximately 33

$\mathrm{kb}$ in length. This allele, which encodes Jupiter microtubule associated homolog 1 protein,

is involved in the modulation of cell adhesion, cell cycle progression and signal transduction. 